\title{
"It's true! I saw it on WhatsApp": Social Media, Covid-19, and Political-Ideological Orientation in Brazil
}

\author{
Mozer de Miranda $\operatorname{Ramos}^{1}$ (D) $\cdot$ Rodrigo de Oliveira Machado $^{1}$ (D) \\ Elder Cerqueira-Santos ${ }^{1}$ (D)
}

Accepted: 25 November 2021 / Published online: 13 January 2022

@ Associação Brasileira de Psicologia 2021

\begin{abstract}
The Covid-19 pandemic in Brazil was widely affected by politics and the population's consumption of information is fundamental to understanding the situation. This study aimed at understanding the relationship between political-ideological markers, consumption of information, and preventive practices during the pandemic. We conducted an online survey with 1,328 Brazilians who answered a questionnaire about authoritarianism, conservatism, political orientation, trust in social media, and preventive practices during the pandemic The results indicate that right-wing and centrist individuals, with higher authoritarianism or higher conservatism scores, put significantly more trust in the information about Covid-19 conveyed through WhatsApp and less trust in the information conveyed through traditional media, in comparison with left-wing individuals or individuals with low scores for these factors. Additionally, these elements were closely associated with worse practices concerning the use of masks, practices of social distancing, and the intention of being vaccinated. The findings warn of the impacts of fake news in health practices during the pandemic.
\end{abstract}

Keywords Covid-19 $\cdot$ Social media $\cdot$ Fake news $\cdot$ Political psychology $\cdot$ Brazil

\section{Introduction}

The first 20 months of the Covid-19 pandemic in Brazil were marked by many deaths, lack of hospital beds, lack of basic supplies, and collapse of the healthcare system, severe economic crisis, an increase of political polarization in the country, and spread of fake news and conspiracy theories (Barberia \& Gómez, 2020; Ferrante et al., 2021; Silva, 2021; Zhu et al., 2020). From the federal government, there

Mozer de Miranda Ramos

mozeramos@gmail.com

1 Postgraduate Degree Program in Psychology, Federal University of Sergipe, Av. Marechal Rondon, s/n Jardim Rosa Elze, São Cristóvão 49100-000, Brazil 
has been encouragement of the use of medications without scientific proof of efficacy, discouragement of social distancing, mask use, and vaccination, and resistance to adhering to large-scale vaccination programs (Burni \& Tamaki, 2021; Ferrante et al., 2021; Guerin, 2021; Monari et al., 2021). With a term that started in 2019, Brazil's president, Jair Bolsonaro, a conservative, right-wing career politician that flirts with authoritarian attitudes, has committed himself to turning the pandemic into a political dispute with a select few opponents: science, health authorities, political rivals, governors and mayors, the press, and even China (Boschiero et al., 2021; Burni \& Tamaki, 2021; Fonseca et al., 2021; Militão, 2021; Monari et al., 2021; Ricard \& Medeiros, 2020), all these as part of an ideological agenda to increase the loyalty of voters and worsen the country's political situation (Barberia \& Gómez, 2020; Ferrante et al., 2021; Soares et al., 2021).

In the context of threat by pathogens (such as the Covid-19 pandemic), a tendency toward increasing authoritarianism and conservatism has already been observed (Pazhoohi \& Kingstone, 2021). This effect seems to result from factors such as the consumption of low-quality information, engagement in targeting this news, and the strengthening of authoritarian and conservative values during the pandemic. In Brazil, Bolsonaro's support would serve as a grant (or incentive) for antiscientific and negationist practices. The association between authoritarianism and conspiracy beliefs regarding the pandemic was described by Prichard and Christman (2020), which would help in understanding the engagement in fake news by a large portion of the Brazilian population. Additionally, conservatism is associated with conspiratorial beliefs regarding the relationship between the media and the virus, and can predict a reduced discernment between real and fake headlines regarding Covid-19 (Calvillo et al., 2020; Roozenbeek, 2020).

In a particular way, Brazil experienced a supposed conflict between healthcare and the economy regarding the pandemic. The tension was increased by the president's argument, which was widely reproduced by his supporters, that sanitary measures would harm the economy. This, in turn, would be the real reason that would cause the economic struggles experienced in Brazil since then (Fonseca et al., 2021). The social inequality that is flagrant in the country has contributed to the fact that this false symmetry can be sustained and used as an anti-healthcare strategy.

The media had a central role in this period of conflict, either through initiatives to inform the population assertively about the virus or by contributing to the spread of misleading information about the pandemic (G1 et al., 2020; Galhardi et al., 2020; Militão, 2021; Monari et al., 2021; Soares et al., 2021). The content of the fake news repeatedly matched the president's agenda. These false reports acted as an agent seeking political support and aiming to mediate the crisis created by the pandemic (Burni \& Tamaki, 2021; Galhardi et al., 2020; Monari et al., 2021; Ricard \& Medeiros, 2020). In 2018, Bolsonaro already went as far as to say that "Even fake news is valid" (Jovem Pan, 2018). In September 2021, he defended that fake news is part of life and acts like little lies that die out without causing problems (Soares, 2021). However, misinformation caused by misleading reports can affect the population's attitude regarding Covid-19 and potentially worsen the sanitary emergency (Allington, Duffy et al., 2021; Allington, Duffy, et al., 2021; Allington, McAndrew, et al., 2021; Freeman et al., 2020; Gramacho 
\& Turgeon, 2021). This does not mean that exaggerations or misleading reports are absent in opposition to the government, but their success or repercussion is reportedly lesser (Edelson et al., 2021; Soares et al, 2021).

Brazil repeatedly lost battles against Covid-19 in part because of the government's actions and in part because of the population's actions (Ricard \& Medeiros, 2020; Zhu et al., 2020). However, one must remember the decisive role that authorities have in how the population conducts itself during the pandemic and how the population's behavior can be influenced by way of conspiracy theories and misinformation (Ferrante et al., 2021; Gramacho \& Turgeon, 2021; Soares et al., 2021).

Several studies, with different complexities, have projected that an important part of the deaths in Brazil due to the Covid-19 pandemic could have been avoided. The numbers found refer to different time periods and indicate scenarios with $56,000,120,000,146,000$, or even 356,000 fewer deaths if there had been better management of the pandemic by the Brazilian government (Lupion, 2021; Werneck et al., 2021). There is even evidence that political alignment with the government is associated with decreased compliance with measures to prevent the spread of the virus, attributing more than 25,000 deaths to political alignment in the 5 months evaluated by the research (Rodrigues et al., 2021).

One study indicated a higher number of cases and deaths from Covid-19 in cities where President Jair Bolsonaro had emerged victorious in the 2018 elections, furthermore demonstrating a worsening of cases and deaths after speeches relativizing pandemic care and encouraging the use of unproven medications in cities where there was broad support for Bolsonaro compared to cities where there was little support for him (Cabral et al., 2021). In addition, studies developed in Brazil have shown on the one hand a mediation of conspiratorial beliefs between political orientation and vaccination intention (Galli \& Modesto, 2021), and on the other hand, a direct relationship between political orientation and engagement in social isolation measures (Modesto et al., 2020).

This work aims to understand the relationship between political-ideological markers, consumption of information, and preventive practices during the pandemic. We investigated, therefore, connections between political orientation, authoritarianism, conservatism, and the attribution of truth to different social communication media (traditional ones and social networks). Additionally, we explored the connection of these elements with preventive practices during the Covid-19 pandemic.

\section{Method}

\section{Ethical Procedures}

This study was approved by the Research Ethics Committee (CAAE 30192720.0.0000.5546). It is a quantitative study conducted through a survey on an online platform. The participants' anonymity was assured and only those who 
agreed with the informed consent form could answer the questionnaire. Informed consent was obtained from all individual participants included in the study.

\section{Participants}

The sample consisted of 1,328 individuals living in Brazil, over 18 years of age, and who agreed to participate in the study. The mean age was 27.5 years $(S D=8.64)$, varying between 18 and 71 years. The states of Minas Gerais (20.4\%), Rio Grande do Sul (19.1\%), Bahia (13.7\%), São Paulo (10.4\%), and Rio de Janeiro (8.6\%) made up $72.1 \%$ of the sample. The five regions of the country were represented: Southeast (42.4\%), Northeast (26.7\%), South (21.5\%), Center-West (6.9\%), and North (2.6\%).

Individuals oriented toward the left-wing of the political spectrum were the most abundant in the sample $(62.6 \% ; n=831)$, followed by centrists $(29.0 \% ; n=385)$ and right-wing individuals $(8.4 \% ; n=112)$. The scholarship of the participants showed a high standard for Brazil, as 48.4\% $(n=643)$ had finished high school and $50.9 \%$ were graduate. Women made up $62.2 \%(n=826)$ of the sample, followed by men $35.5 \%(n=472)$ and other identities $2.3 \%(n=30)$. Only $1.3 \%(n=17)$ declared to be transgender. Heterosexuals were predominant $(66.3 \% ; n=880)$, followed by bisexuals $(17.0 \% ; n=226)$ and homosexuals $(12.5 \% ; n=166)$. Other sexual orientations accounted for $4.2 \%(n=56)$. The ethnic-racial identity of most of the participants was white $(63.3 \% ; n=841)$ and black $(34.6 \% ; n=459)$. Other identities made up $2.1 \%(n=28)$. The sample was essentially urban $(95.5 \% ; n=1,268)$.

\section{Instruments}

We used standardized instruments for research and a social identity questionnaire containing identification data such as age and gender. The questionnaire developed by the authors for this study also detailed preventive practices during the pandemic (mask use, intention to be vaccinated and practices of social distancing), use of social networks (through graded multiple-choice answers), and attribution of truth to the media regarding the Covid-19 pandemic (ATM) (through 5-point Likert-type questions, with the option of indicating or not the use of the platform in question). The political orientation was answered with a 3-point question: left-wing, center, or the right-wing. Another instrument used was the Right-Wing Authoritarianism scale (RWA; RMSEA =0.069, 90\% CI [0.065, 0.072]; CFI =0.96; TLI =0.95; Vilanova et al., 2018), of which, only 20 items were applied (5-point Likert scale) corresponding to the factors of authoritarianism $(\alpha=0.888 ; \omega=0.891)$ and traditionalism $(\alpha=0.839 ; \omega=0.837)$, as the most informative and discriminative factors in Brazil, according to the authors, to evaluate authoritarianism and traditionalist conservatism, respectively. Traditionalism is best understood in Brazil as traditionalist conservatism, a construct associated with conservatism of manners. Therefore, we treat this variable as "conservatism" in this paper. 


\section{Procedures}

The instruments were organized into an online research form that was available from 27 January 2021 to 16 March 2021. The mean time spent by the respondents was about $20 \mathrm{~min}$. The invitation for the form was shared via social networks (Instagram, Facebook, WhatsApp, and Twitter) and institutional e-mails of the universities. After this stage, the data was organized into a database and analyzed using statistical software.

\section{Procedures of Data Analysis}

JASP software was used and descriptive statistics of the researched data were produced. Additionally, tests of means were conducted ( $t$-test or ANOVA) and were used to evaluate the differences of authoritarianism, conservatism, and ATM regarding political orientation and preventive practices with the pandemic. For the post hoc analysis of the ANOVA, we used the Games-Howell test. We conducted a chisquared test to evaluate the independence between the preventive practices with the pandemic and political orientation. Additionally, we conducted a correlation between conservatism, authoritarianism, and ATM.

\section{Results}

\section{Social Networks}

In the question about which social networks the participants used daily, Instagram was highlighted by $82.8 \%(n=1,099)$ of the participants. Facebook was chosen by $46.8 \%(n=621)$, Twitter by $37.7 \%(n=500)$, WhatsApp by $95.6 \%(n=1,269)$, YouTube by $74.1 \%(n=984)$, LinkedIn by $18.6 \%(n=247)$, and other social networks by $7.0 \%(n=93)$. The average number of hours spent by the participants in each social network were estimated and varied from 0 to $12 \mathrm{~h}$. WhatsApp had the highest mean dedicated time, $3.84 \mathrm{~h}(S D=3.18)$, followed by Instagram $(M=2.60 ; D P=2.37)$, YouTube $(M=2.32 ; D P=2.31)$, Twitter $(M=1.94 ; D P=2.33)$, Facebook $(M=1.31$; $D P=1.91)$, and LinkedIn $(M=0.59 ; D P=1.34)$.

\section{Information and Media}

The respondents of this investigation indicated the frequency with which they actively sought information regarding the Covid-19 pandemic. Those that indicated that they never did it made up 5.5\% $(n=73)$, rarely $22.4 \%(n=297)$, sometimes $37.7 \%(n=501)$, frequently $26.7 \%(n=355)$, and very frequently $7.7 \%(n=102)$. Moreover, they indicated the main information sources used by them regarding the Covid-19 pandemic. The online news portals were selected by $68.2 \%(n=906)$ and 
free television channels by $50.8 \%(n=675)$. Paid television channels were used by $25.2 \%(n=335)$, printed newspapers and magazines by $8.2 \%(n=109)$, and radio programs by $8.8 \%(n=117)$. Social media was also important in this function of providing information: Facebook $18.8 \%(n=250)$, Instagram $38 \%(n=505)$, WhatsApp $13.1 \%(n=174)$, YouTube $17.0 \%(n=226)$, and Twitter $25.0 \%(n=332)$. The respondents also indicated how much they considered as true of the information regarding the Covid-19 pandemic that was shared on these platforms. The results are described in Table 1.

The ATM variables, together with the measures of authoritarianism and conservatism, were subjected to one-way ANOVAs to investigate the differences between the political orientation groups. The results are described in Table 2.

Unpacking the ANOVAs described in Table 2, one has the following: (a) In the measurement of authoritarianism, left-wing and center $(p<0.001$; Cohen's $d=1.04)$, left-wing and right-wing $(p<0.001$; Cohen's $d=1.81)$, and center and right-wing ( $p<0.001$; Cohen's $d=0.70$ ) were significantly different. In the measurement of conservatism, there was also a significant difference between left-wing and center $(p<0.001$; Cohen's $d=0.79)$, left-wing and right-wing $(p<0.001$; Cohen's $d=1.25)$, and center and right-wing ( $p=0.048$; Cohen's $d=0.26)$.

(b) Regarding the attribution of truth to information found on free television, we see again a significant difference between left-wing and center $(p<0.001$; Cohen's $d=0.31$ ), left-wing and right-wing ( $p<0.001$; Cohen's $d=0.84)$, and center and right-wing ( $p=0.007$; Cohen's $d=0.41)$. Regarding paid television, in turn, there was only a significant difference between left-wing and center $(p<0.001$; Cohen's $d=0.36)$ and left-wing and right-wing ( $p<0.001$; Cohen's $d=0.62)$. With the online portals, we found again significant differences between all pairs: left-wing and center $(p<0.001$; Cohen's $d=0.34)$, left-wing and right-wing $(p<0.001$; Cohen's $d=0.79)$, and center and right-wing $(p=0.007$; Cohen's $d=0.37)$. Likewise, all three groups differed regarding printed newspapers and magazines: left-wing and center $(p<0.001$; Cohen's $d=0.36)$, left-wing and right-wing $(p<0.001$; Cohen's $d=1.10)$, and center and right-wing ( $p=0.001$; Cohen's $d=0.59)$.

(c) Concerning Facebook and YouTube, although the tests were significant, the groups did not differ. For WhatsApp, however, there was a significant difference between left-wing and center $(p<0.001$; Cohen's $d=0.42)$ and left-wing and right-wing ( $p<0.001$; Cohen's $d=0.56$ ), while for Twitter, only left-wing and center ( $p<0.001$; Cohen's $d=0.38$ ) were significantly different. Right-wing and center had the same mean, but the sample size did not allow for significance between left-wing and right-wing.

Correlation coefficients between the ATMs and the measurements of authoritarianism and conservatism were produced. These results are described in Table 3. Authoritarianism and conservatism were positively and moderately correlated $(\rho=0.436 ; p<0.001)$. 


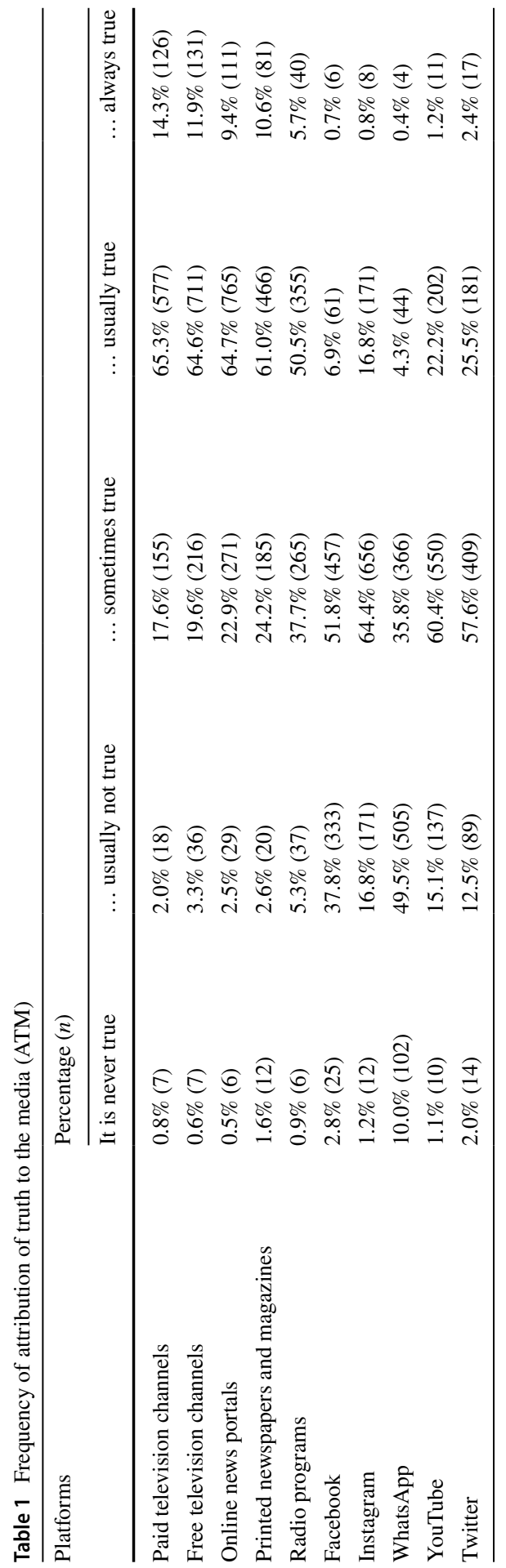




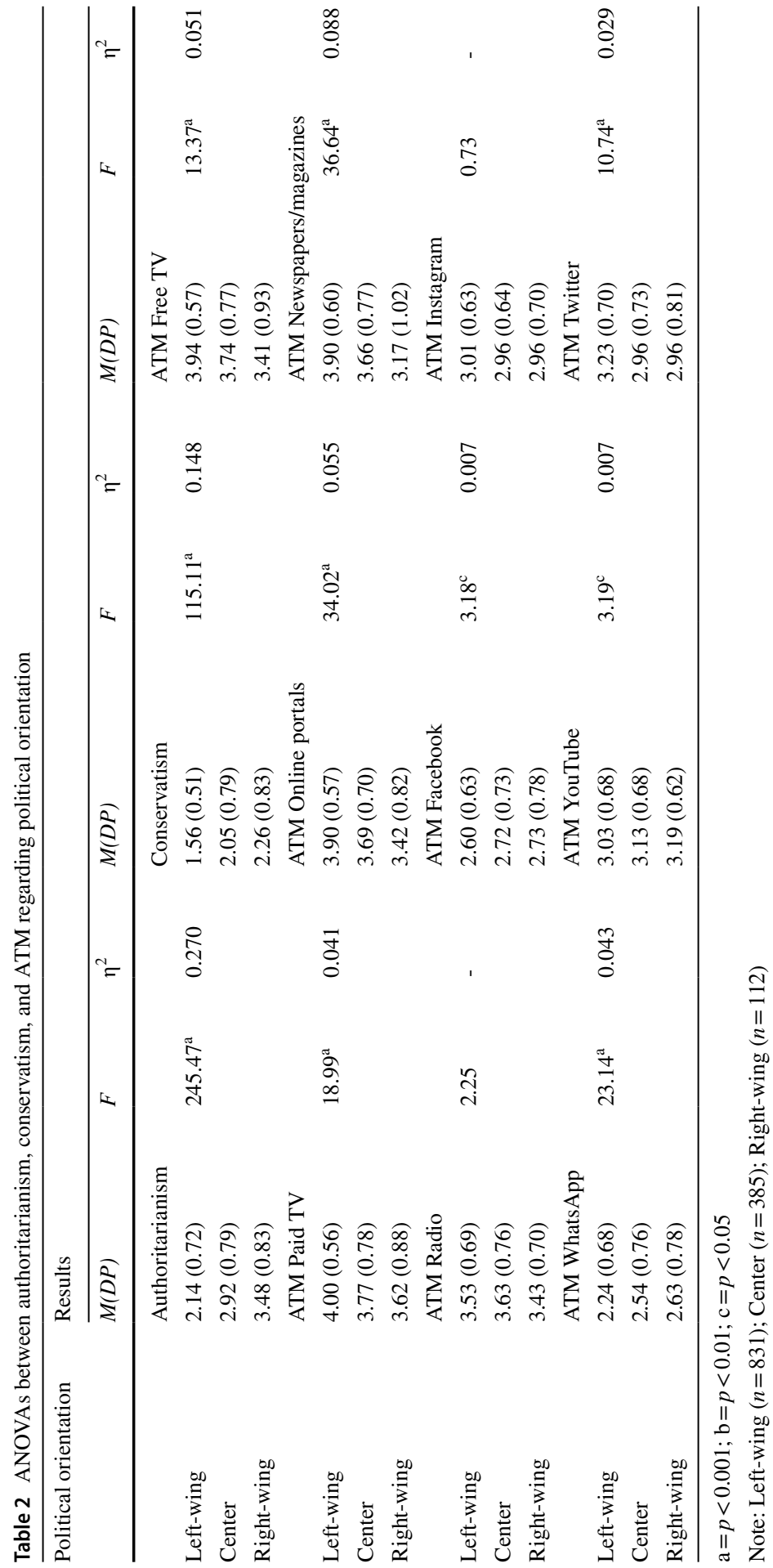


Table 3 Spearman's correlation coefficients between authoritarianism, conservatism, and ATM

\begin{tabular}{lll}
\hline & Correlation coefficient $\rho$ & \\
\hline & Authoritarianism & Conservatism \\
ATM Free television channels & $-0.102 * *$ & $-0.149 * *$ \\
ATM Paid television channels & $-0.103 * *$ & $-0.157^{* *}$ \\
ATM Online news portals & $-0.132^{* *}$ & $-0.147^{* *}$ \\
ATM Printed newspapers or magazines & $-0.115^{*}$ & $-0.175^{* *}$ \\
ATM Radio programs & 0.067 & 0.023 \\
ATM Facebook & $0.186^{* *}$ & $0.094^{* *}$ \\
ATM Instagram & 0.052 & -0.031 \\
ATM WhatsApp & $0.229 * *$ & $0.219 * *$ \\
ATM YouTube & $0.095^{* *}$ & $0.082^{* *}$ \\
ATM Twitter & -0.030 & $-0.094^{*}$ \\
\hline
\end{tabular}

$* *=p<0.01 ; *=p<0.05$

\section{Practices During the Pandemic}

Only $5.2 \%(n=69)$ of the respondents are not sure whether they will vaccinate or are sure that they will not. Among these, $8.7 \%(n=6)$ justified that they do not believe it to be necessary, $37.9 \%(n=26)$ believe it is not effective, $46.4 \%(n=32)$ believe it can cause health damage, $7.2 \%(n=5)$ claimed political reasons, and $31.9 \%(n=22)$ indicated other reasons, almost all linked to distrust on the effectiveness and possible negative effects caused by the vaccine.

On following social distancing, $31.3 \%(n=415)$ think they are following the norms strictly, while $65.4 \%(n=868)$ said to be following them flexibly, and $3.4 \%$ $(n=45)$ are not following the recommendations. The main justification was linked to economic reasons $(39.9 \% ; n=364)$, e.g., need for leaving home to work. Only $6.6 \%$ $(n=60)$ claimed that it is unnecessary, $7.0 \%(n=64)$ believe it is inefficient, $24.9 \%$ $(n=227)$ believe it can cause health problems, $2.0 \%(n=18)$ claimed religious reasons, and $0.8 \%(n=7)$ claimed political reasons. Other justifications made up $37.3 \%$ ( $n=341$ ), the main ones being essential tasks (going to the market or pharmacy), visitations, "psychological," "well-being" and "mental health" needs, and work.

Regarding the use of masks, only $11.5 \%(n=153)$ admitted an inconsistent use. Of these, $26.1 \%(n=40)$ believe it is not efficient, $15.0 \%(n=23)$ that it is unnecessary, and $13.7 \%(n=21)$ that it can cause health damage. Economic reasons were pointed out by $5.2 \%(n=8)$ and religious reasons by $4.5 \%(n=7)$. Other reasons were pointed out by $45.4 \%(n=71)$, the main ones being discomfort and lack of habit.

Considering authoritarianism, conservatism, and ATM, there were significant differences in $t$-tests comparing the groups that are sure and unsure about receiving the vaccine, the groups that have maintained rigorous and flexible social distance, and the groups that use masks rigorously and flexibly. The groups in which these differences were identified are described in Table 4. 


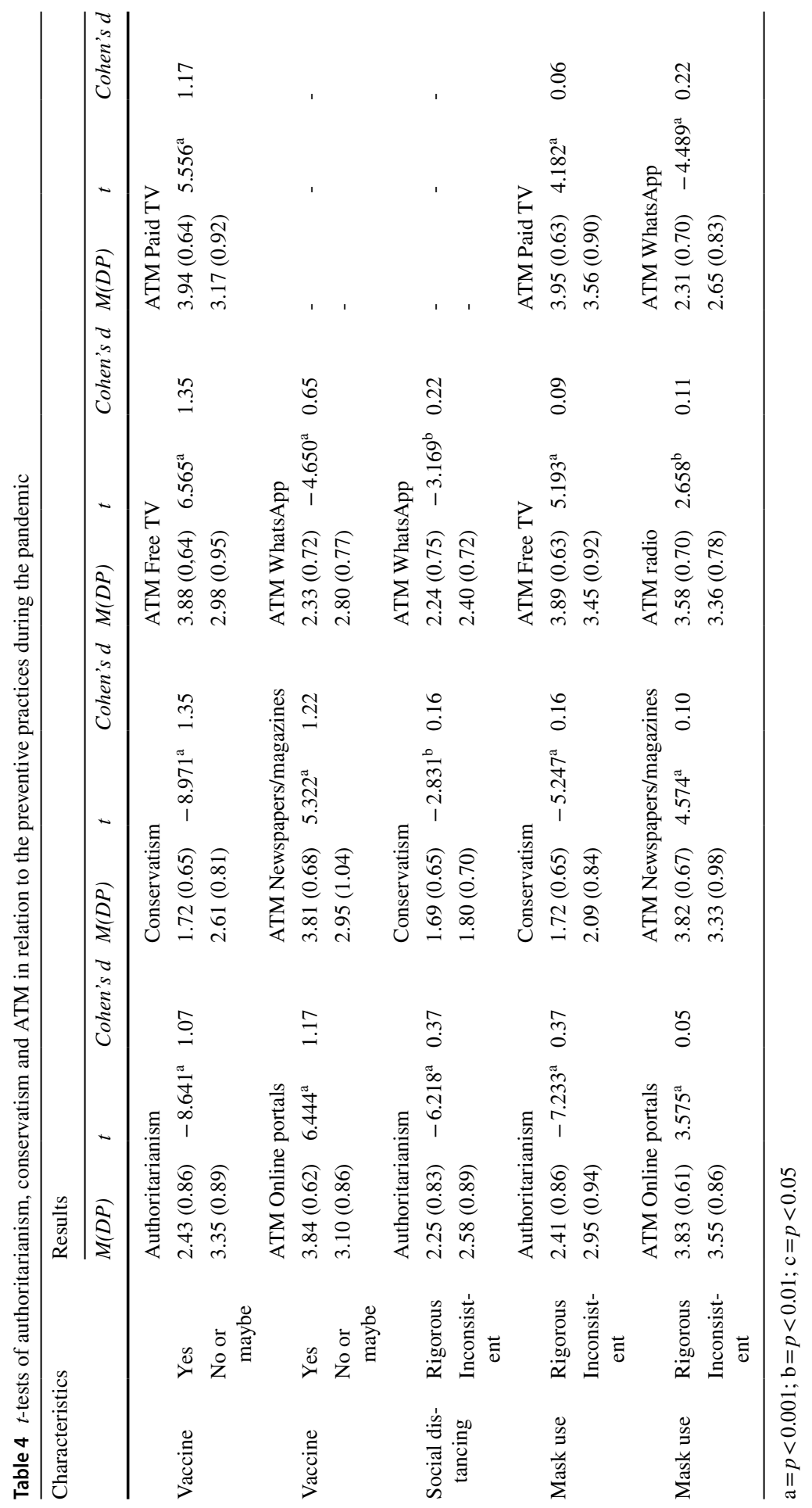


Political orientation was associated with preventive practices during the pandemic: intention of being vaccinated $\left(\chi^{2}(2)=117.528 ; p<0.001 ; V=0.297\right)$, consistency in social distancing $\left(\chi^{2}(2)=16.821 ; p<0.001 ; V=0.113\right)$, and consistency in mask use $\left(\chi^{2}(2)=45.202 ; p<0.001 ; V=0.184\right)$. Analyses of adjusted standardized residuals showed that the left-wing was associated with the group that was sure about the intention of being vaccinated and with the groups of consistent social distancing and mask use. The associations of the center and right-wing were in the opposite direction (uncertainty and inconsistency). The only exception was that the right-wing was not significantly associated with the practice of social distancing.

\section{Discussion}

In our sample, WhatsApp was the social network used by the largest number of participants and for the longest time, followed by Instagram and YouTube. The results also highlighted an association between the attribution of truth to news spread through this platform and inadequate practices to fight the Covid-19 pandemic. In Brazil, the use of WhatsApp extrapolated the limits of entertainment and informality in the last years and has been used institutionally as a strategy to reach people and bring them close (Lima et al., 2018), which was enhanced during the pandemic, as it demanded new communication technologies in the face of the affected social context (Faria \& Fonseca, 2021; Hallwass \& Bredow, 2021).

The traditional media vehicles were listed as the main sources of information regarding the pandemic, with highlights to the online news portals and free television. However, an important portion mentioned social media as sources to become informed about the pandemic, which indicates that the diverse possibilities of content production also impact the information process of the population either on opinion spaces, such as Twitter, or through the sharing of news, e.g., through WhatsApp. This media model in which the editors and the news selection do not follow fact-checking principles but rely on clickbait and the supposed credibility of the sender (who is not always the one that created the information/ opinion) has been producing a serious problem, with the population engaging in fake news (Soares et al., 2021). The repercussions go from impacts in the political processes to changes in the adoption of behaviors during the Covid-19 pandemic (Barcelos et al., 2021; Delmazo \& Valente, 2018; Pinto et al., 2021).

The engagement in fake news is associated with disbelief in the traditional media and more trust in the government (when one's side is in power) (Ognyanova et al., 2020). Altruistic motivation, search for socialization, sharing of news as a pastime, search for information, and interest in sharing information are predictors found by Apuke and Omar (2021) for the sharing of fake news. Commonly, the sharing and adoption of such misleading reports as beliefs occur without the awareness of it being fake content. A portion of the population admits to sharing fake news intentionally, while others say that they refute shares when they find them to be fake content (Baptista et al., 2019). However, commitment in the latter is often not as intense as in the former and there are many difficulties in correcting the creation of beliefs that are already widespread in the population. 
Additionally, people with low cognitive ability have more difficulty in adjusting (reformulating) attitudes based on fake news when they find out that it is fake (Keersmaecker \& Roets, 2017). On the other hand, other authors argue that presenting tips for digital literacy can improve the capacity to distinguish fake and legitimate news (Guess et al., 2020).

Misleading reports related to the use of medication that would prevent Covid19 infection (e.g., chloroquine, azithromycin, and ivermectin) impacted daily life in Brazil during the Covid-19 pandemic (Cardoso, 2021). Physicians, the President, and even the Ministry of Health openly supported what they called "early treatment" or "covid kit" without scientific elements in place for such a practice (Diário do Nordeste, 2021; Médicos pela Vida, 2021). The government even launched an application, "TrateCov," that systematically prescribed the "early treatment" with these medications (Secom TCU, 2021). While the content regarding these medications had already been overcome in other countries, the year 2021 was still marked by this discussion in Brazil (Poder360, 2021). In his speech at the United Nations in September 2021, the president reiterated his defense of the indiscriminate use of medications without scientific evidence to fight Covid19 (Estadão, 2021). In the face of the increased sale of these medications (André, 2021), part of the population shares a supposed belief in protection (and decreases in the necessary care) and many started to suffer the consequences of intoxication caused by these medications (Alves \& Carneiro, 2021; Batista, 2021).

WhatsApp, Facebook, and Instagram have been pointed out as the main vehicles for the spread of fake news about the Covid-19 pandemic in Brazil, causing publichealth harm (Baptista et al., 2019; Galhardi et al., 2020). Possibly, for this reason, in our sample, the traditional media received a better evaluation of attribution of truth than social media, with WhatsApp and Facebook being the most discredited in contrast with their intense use for other purposes. These results agree with the data produced even before the pandemic period (Baptista et al., 2019).

Evaluating the association between political orientation and attribution of truth to information media, left-wing individuals trusted more intensely, followed by the center (except for paid television), in the more traditional media vehicles: free television and paid television, online news portals, and newspapers/magazines. Twitter also had significantly higher attribution of truth from the left-wing in relation to the center (and right-wing, with the proper statistical remarks). The effect sizes, mainly from the relationships between left-wing and right-wing, were from medium to high. Centrist and right-wing individuals showed more trust in WhatsApp than left-wing individuals. The study of Baptista et al. (2019) indicated that $57 \%$ of their Brazilian sample considered WhatsApp an important source to be informed about politics, while Facebook reached $64 \%$.

The differences between the political spectra also extended to the measurements of authoritarianism and conservatism. The right-winged group had significantly higher means (and with large effect sizes) than the left-winged group in these measurements. Regarding the center, the differences were also significant. However, the centrist group also had significantly higher levels of authoritarianism and conservatism than the left-wing. Reinforcing this result, the measurements of authoritarianism and conservatism were correlated negatively (with low intensity) with the 
attribution of truth to traditional media, while the attribution of truth to social media (Facebook, WhatsApp, and YouTube) showed positive correlations, with highlight on a slightly higher value of these measurements with WhatsApp. Only Twitter showed a negative correlation (with very low intensity) with conservatism.

It is important to put into perspective the Brazilian political context, which is going through a delicate moment, with strong political polarization (democracy vs. dictatorship, left-wing vs. right-wing, minorities vs. hegemonic groups) and threats of institutional rupture. The experienced disputes go beyond the political debate and affect identity aspects and the order of affections far beyond the factual elements (feeding or not into fake news). Control of the discourse has been disputed viscerally, as dictated by the country's government. The use of bots (automated profiles on social networks) to spread ideas and fake news has been interfering in the country's course in recent years (Arnaudo, 2017; Soares \& Fernandes, 2021). On several occasions, president Bolsonaro attacked the approach of traditional media on the pandemic and discouraged their use (G1 et al., 2020; Militão, 2021). This helps understand the scenario in which the credibility of those that share the same political field as the country's ruler migrates toward social networks, which are systematically used to spread misleading information and control the discourses, rejecting the traditional media, which are misjudged by Bolsonaro.

We suggest, as an explanatory hypothesis, that believing or not in information, in a journalist or scientist, became an identity dispute connected to one's group identity. Changing this system of beliefs is related to the change of affections and not only to the opposition of ideas or the resolution of fake news about the Covid-19 pandemic. Kahan (2017) reminds that the individuals' cultural predisposition is independent and anterior to the misinformation, highlighting the highly antagonistic environment as a driver of this identity polarization. The taken positions pose as fundamental to transmit "who they are" and "on which side" they are. Thus, the information is connected to identity, and not to what is accurate according to the facts. It is a matter of loyalty, group connection, and belonging. This mode of information processing is called ideologically motivated cognition for identity protection, promoting the interest in forming and maintaining the beliefs associated with identity. Individuals that are engaged in this cognitive model would tend to be more resistant to correction and information that seems like attacks on their identity, besides failing more in the task of distinguishing fake and actual news, favoring whatever agrees with them ideologically (Kahan, 2012, 2017; Van Bavel \& Pereira, 2018).

However, this explanation is not a consensus. A review favors the lack of careful reasoning and relevant knowledge, as well as the source's familiarity and heuristics, as an explanation for the poor judgment concerning fake news (Pennycook \& Rand, 2021). Analytical thinking and deliberation can reduce the inaccuracy of fake news and would have as a true antagonist the quick and lazy deliberations (Bago et al., 2020; Pennycook, \& Rand, 2019; Stanley et al., 2021). Despite being based on different theoretical models, the findings are not always incompatible. The familiarity and heuristics of the source are important tools to understand the processing of fake news in any of these models, even considering the differences in approach and function. 
The attitudes related to the pandemic were also surveyed in this study and the results conform to other studies conducted during the pandemic (Allington, Duffy et al., 2021a; Roozenbeek, 2020a; Rothgerber et al., 2020). The uncertainty or negativity about vaccination was motivated mainly by beliefs of ineffectiveness and unnecessity, as well as by political motivations. Additionally, it was associated with large effect sizes, more authoritarianism and conservatism, less attribution of truth to free television and paid television, online news portals, and newspapers/magazines. It was also associated with an increased attribution of truth to information coming from WhatsApp and centrist and right-wing groups, with moderate effect sizes.

Regarding the non-compliance or inconsistency of social distancing, economic reasons (such as the need to work) and the promotion of one's well-being were the main factors. It was shown to be associated with increased mean values of authoritarianism and conservatism, centrist political orientation, and increased attribution of truth to news from WhatsApp. Mask use was challenged mainly due to reasons linked to discomfort and beliefs in inefficiency. The inconsistency in use was associated with a higher score of authoritarianism and conservatism, increased attribution of truth to WhatsApp, decreased attribution of truth to other media (free television, paid television, online news portals, newspapers/magazines, and radio), and centrist and right-wing groups. The effect sizes of these associations were small and medium, the most relevant ones being linked to authoritarianism and attribution of truth to WhatsApp.

The effect sizes related to the differences of authoritarianism, conservatism, and ATM regarding the groups that represent the actions of care in relation to the pandemic, presented in Table 4, were large with vaccination (moderate only with respect to WhatsApp) and small with the other indicators, mask use, and social isolation. The interpretation of these effect sizes would indicate, at first, that with respect to vaccination, there is a more discriminating relationship than with the other care. An explanatory hypothesis about this could be related to the period in which the research was conducted, in which vaccination was the most current and inserted subject, while the previous ones seemed to have been more popular. Even in relation to WhatsApp that showed moderate effect size $(0.65)$ with respect to vaccination, in the other indicators, the effect was similar and small (0.22). The information circulating in the country at the time of the survey focused on vaccination, either because of the lack of vaccines in quantity, the delay in starting vaccination, the widespread suspicions, or the fake news that intended to undermine the population's confidence in the Covid-19 vaccines.

The relationship between healthcare behaviors related to the pandemic and authoritarianism and conservatism is supported by the literature, highlighting the relationship between these constructs and the susceptibility to fake news (Corpuz et al., 2020; Prichard \& Christman, 2020; Roozenbeek, 2020; Rothgerber et al., 2020). The smaller concern with the virus and the resistance in adopting adequate behaviors for this context are discussed in the literature through the cognitive functioning that is linked to these political traits (Jost et al., 2003; Van Hiel \& De Clercq, 2009). 
A negative relationship of right-wing groups with preventive practices during the pandemic was also described by another study in the Brazilian context (Ramos et al., 2020). The authors indicate that political orientation was able to predict the support of social distancing and the decision to donate to health-related causes. The option "center" was not available in this study, but this group is partially supported by the results (Ramos et al., 2020). The political orientation and the ideological congruence with the ruling political leaders have a fundamental role in the management of health-related behaviors during the pandemic, again associating the right-wing with negative behaviors in the fight against Covid-19 (Barbieri \& Bonini, 2021; Gadarian et al., 2021). This does not mean that left-wing individuals, or those that are a little conservative and authoritarian, cannot engage in fake news, but these contents seem to have less success in those groups, with the two political extremes being more associated with these practices (Edelson et al., 2021; Soares et al., 2021).

Finally, the preference for searching for information on social media, especially WhatsApp, and the disbelief in traditional media were also associated with worse preventive practices during the pandemic by several studies hesitation regarding vaccination (Allington, especially the, Duffy et al., 2021a; Allington, Duffy, et al., 2021; Allington, McAndrew, et al., 2021; Freeman et al., 2020). This is because the belief in conspiracy theories and fake news is associated with increased inconsistency in preventive practices concerning Covid-19 (Allington et al., 2021a; Bertin et al., 2020; Roozenbeek, 2020a). Thus, the preference for media with little credibility in spreading good information, such as WhatsApp, can serve as an incubator for worse preventive practices. This study found evidence that connects politicalideological orientation to health practices during the Covid-19 pandemic, with fake news being one of the elements that can affect this relationship.

Thus, for the collective health and success in the dispute with the pandemic scenario, it is fundamental to adopt measures to fight misinformation and interventions to increase the population's discernment regarding the Covid-19 pandemic. However, it is necessary to be careful so that the adopted strategies do not work as attacks to one's identity (Kahan, 2012, 2017; Van Bavel \& Pereira, 2018), thus increasing the efficacy regarding the most vulnerable groups in the country: increased conservatism, increased authoritarianism, and people with little literacy in social media and with a center-right political orientation. The role of social and political psychology to produce mechanisms that circumvent the emotional charge of these beliefs is challenging. The production of health-related content and popular science also need to develop mechanisms to mitigate the impact of fake news and its predictors in the population.

Furthermore, prevention techniques are extremely necessary and promisingly effective to prevent misinformation and its harmful consequences, whether through digital literacy (Guess et al., 2020) or through psychological inoculation and prebunking (Van Der Linden et al., 2020). This method, in analogy to the vaccination process, consists of promoting "antibodies" in the population to combat misinformation. This would happen through exposure to weakened versions of misinformation persuasion, increasing their "immunity" to other situations, persuasive attacks, and disinformation (Lewandowsky \& Van Der Linden, 2021). Efficacy has even been demonstrated in relation to issues related to Covid-19, vaccination, political 
polarization, and conspiracy theories (Basol et al., 2021; Roozenbeek, Schneider, et al., 2020; Roozenbeek, van der Linden, et al., 2020).

Future studies must focus on investigating the predictive power of political orientation, as well as conservatism and authoritarianism traits, in the trust on social media and the engagement in healthcare behaviors. One of the limitations of this study refers to the difficulty in accessing a larger sample of the right-wing and/or connected to conservative values. The researchers had difficulty in stimulating this group to answer the questionnaire. The subject of Covid-19 and the social representations linked to science, in the tense context of political polarization, possibly pushed away part of the respondents that are more closed in their social groups and little open to contribute to studies that supposedly would not reflect their values. Additionally, we were unable to investigate the influence of economic status on the studied variables. This study restates the importance of Brazilian psychology to embrace evidence-based practice to guide actions to promote health and social welfare.

This study contributed to establishing the relationship between misinformation and health behaviors, pointing out that a greater trust in news conveyed on social networks can mean a vulnerability to the individual's health behaviors. Furthermore, it was important to point out how the Brazilian political context constructed such a relationship, evidencing less desirable behaviors (regarding information consumption and pandemic care) in the right-wing (or center) group, as well as in individuals with higher scores in authoritarianism or conservatism. However, it is known that predictive studies are necessary for the understanding of the dimensions of the phenomenon pointed out in this research. When authorities or individuals with high social projection engage in producing misinformative content, social networks end up being a profitable space for the resonance of this harmful network to science, to the population, and to society.

Acknowledgements We thank Coordenação de Aperfeiçoamento de Pessoal de Nível Superior (CAPES) for funding scholarships.

Author Contribution All authors contributed to the study conception and design. Material preparation, data collection, and analysis were performed by Mozer de Miranda Ramos, Rodrigo de Oliveira Machado, and Elder Cerqueira-Santos. The first draft of the manuscript was written by Mozer de Miranda Ramos, and all authors commented on previous versions of the manuscript. All authors read and approved the final manuscript.

Funding This work was supported by Coordenação de Aperfeiçoamento de Pessoal de Nível Superior (CAPES) and Conselho Nacional de Desenvolvimento Científico e Tecnológico (CNPq). The first author has a doctoral fellowship by CAPES, the second author receives a post-doctoral fellowship (PNPD) by CAPES, and the third author has a productivity fellowship by CNPq.

Coordenação de Aperfeiçoamento de Pessoal de Nível Superior,Conselho Nacional de Desenvolvimento Científico e Tecnológico

Data Availability The data that support the findings of this study are available from the corresponding author upon request. 


\section{Declarations}

Ethics Approval This study was performed in line with the principles of the Declaration of Helsinki. Approval was granted by the Ethics Committee of Comissão Nacional de Ética em Pesquisa (CAAE 30192720.0.0000.5546). Informed consent was obtained from all individual participants included in the study.

Conflict of Interest The authors declare no competing interests.

\section{References}

Allington, D., Duffy, B., Wessely, S., Dhavan, N., \& Rubin, J. (2021). Health-protective behaviour social media usage and conspiracy belief during the COVID 19 public health emergency. Psychological medicine, 51(10), 1763-1769. https://doi.org/10.1017/S003329172000224X

Allington, D., McAndrew, S., Moxham-Hall, V. L., \& Duffy, B. (2021b). Media usage predicts intention to be vaccinated against SARS-CoV-2 in the US and the UK. Vaccine, 39(18), 2595-2603. https:// doi.org/10.1016/j.vaccine.2021.02.054

Alves, I., \& Carneiro, K. (2021, January 20). Infectologista relata complicações em pacientes por uso de medicamentos em "tratamento precoce" contra Covid-19. G1. Retrieved September 23, 2021, from https://g1.globo.com/pb/paraiba/noticia/2021/01/20/infectologista-relata-complicacoes-empacientes-por-uso-de-medicamentos-em-tratamento-precoce-contra-covid-19.ghtml

André, N. (2021, May 6). Venda de ivermectina cresce $857 \%$ no último ano. CNN Brasil. Retrieved September 23, 2021, from https://www.cnnbrasil.com.br/saude/venda-de-iverm ectina-cresce-857-no-ultimo-ano/

Arnaudo, D. (2017). Computational propaganda in Brazil: Social bots during elections. Project on Computational Propaganda, 8. Retrieved September 23, 2021, from https://blogs.oii.ox.ac.uk/politicalb ots/wp-content/uploads/sites/89/2017/06/Comprop-Brazil-1.pdf

Bago, B., Rand, D. G., \& Pennycook, G. (2020). Fake news, fast and slow: Deliberation reduces belief in false (but not true) news headlines. Journal of Experimental Psychology: General, 149(8), 16081613. https://doi.org/10.1037/xge0000729

Baptista, E. A., Rossini, P., Oliveira, V. V., \& Stromer Galley, J. (2019). A circulação da des informação política no WhatsApp e no Facebook The circulation of political (mis)information on WhatsApp and Facebook. Lumina, 13(3), 29-46. https://doi.org/10.34019/1981-4070.2019.v13.28667

Barberia, L. G., \& Gómez, E. J. (2020). Political and institutional perils of Brazil's COVID-19 crisis. The Lancet, 396(10248), 367-368. https://doi.org/10.1016/S0140-6736(20)31681-0

Barbieri, P. N., \& Bonini, B. (2021). Political orientation and adherence to social distancing during the COVID-19 pandemic in Italy. Econ Polit, 38, 483-504 (2021). https://doi.org/10.1007/ s40888-021-00224-w

Barcelos, T. D. N., Muniz, L. N., Dantas, D. M., Cotrim Junior, D. F., Cavalcante, J. R., \& Faerstein, E. (2021). Análise de fake news veiculadas durante a pandemia de COVID-19 no Brasil. Revista Panamericana de Salud Pública, 45, e65. https://doi.org/10.26633/RPSP.2021.65

Basol, M., Roozenbeek, J., Berriche, M., Uenal, F., McClanahan, W. P., \& Linden, S. V. D. (2021). Towards psychological herd immunity: Cross-cultural evidence for two prebunking interventions against COVID-19 misinformation. Big Data \& Society, 8(1), 20539517211013868. https://doi.org/ $10.1177 / 20539517211013868$

Batista, E. L. (2021, January 23). Médicos e pacientes relatam efeitos colaterais graves do chamado "tratamento precoce" contra Covid. Folha de S. Paulo. Retrieved September 23, 2021, from https:// www1.folha.uol.com.br/equilibrioesaude/2021/01/medicos-e-pacientes-relatam-efeitos-colateraisgraves-do-chamado-tratamento-precoce-contra-covid.shtml

Bertin, P., Nera, K., \& Delouvée, S. (2020). Conspiracy beliefs, rejection of vaccination, and support for hydroxychloroquine: A conceptual replication-extension in the COVID-19 pandemic context. Frontiers in Psychology, 11, 565128. https://doi.org/10.3389/fpsyg.2020.565128 
Boschiero, M. N., Palamim, C., \& Marson, F. (2021). COVID-19 vaccination on Brazil and the crocodile side-effect. Ethics, Medicine, and Public Health, 17, 100654. https://doi.org/10.1016/j.jemep.2021. 100654

Burni, A., \& Tamaki, E. (2021). Populist communication during the Covid-19 pandemic: The case of Brazil's President Bolsonaro. Partecipazione e Conflitto, 14(1), 113-131. https://doi.org/10.1285/ i20356609v14i1p113

Cabral, S., Pongeluppe, L., \& Ito, N. (2021). The disastrous effects of leaders in denial: Evidence from the COVID-19 crisis in Brazil. Preprint. (April 28, 2021). Retrieved September 23, 2021. Available at SSRN: https://ssrn.com/abstract=3836147 or https://doi.org/10.2139/ssrn.3836147

Calvillo, D. P., Ross, B. J., Garcia, R. J., Smelter, T. J., \& Rutchick, A. M. (2020). Political ideology predicts perceptions of the threat of COVID-19 (and susceptibility to fake news about it). Social Psychological and Personality Science, 11(8), 1119-1128. https://doi.org/10.1177/1948550620940539

Cardoso, J. (2021, August 20). Farmacêutica e grupo de médicos são processados em R\$ 55 milhões por anúncio de 'tratamento precoce.' Repórter Brasil. Retrieved September 23, 2021, from https:// reporterbrasil.org.br/2021/08/farmaceutica-e-grupo-de-medicos-sao-processados-em-55-milhoesde-reais-por-anuncio-de-tratamento-precoce/

Corpuz, R., D’Alessandro, S., Adeyemo, J., Jankowski, N., \& Kandalaft, K. (2020). Life history orientation predicts COVID-19 precautions and projected behaviors. Frontiers in Psychology, 11, 1857. https://doi.org/10.3389/fpsyg.2020.01857

Delmazo, C., \& Valente, J. C. (2018). Fake news nas redes sociais online: propagação e reações à desinformação em busca de cliques. Media \& Jornalismo, 18(32), 155-169. https://doi.org/10.14195/ 2183-5462_32_11

Diário do Nordeste. (2021, April 23). Ministro da Saúde cogita cloroquina e ivermectina em protocolo de remédios contra Covid-19. Diário do Nordeste. Retrieved September 23, 2021, from https://diari odonordeste.verdesmares.com.br/ultima-hora/pais/ministro-da-saude-cogita-cloroquina-e-iverm ectina-em-protocolo-de-remedios-contra-covid-19-1.3076873

Edelson, L., Nguyen, M., Goldstein, I., Goga, O., Lauinger, T., \& McCoy, D. (2021, March 4). Far-right news sources on Facebook more engaging - Cybersecurity for Democracy. Medium. Retrieved September 23, 2021, from https://medium.com/cybersecurity-for-democracy/far-right-news-sources-onfacebook-more-engaging-e04a01efae 90

Estadão. (2021, September 21). Bolsonaro discursa na ONU e abre 76 a Assembleia-Geral; acompanhe. Política - Estadão. Retrieved September 23, 2021, from https://politica.estadao.com.br/ao-vivo/discu rso-bolsonaro-onu-2021/733217

Faria, D. A., \& Fonseca, P. H. N. (2021). WhatsApp® como Recurso para a Educação em Saúde: Acompanhamento de grupo de cessação do tabagismo diante da pandemia da COVID-19. Research, Society and Development, 10(7), e2910716166-e2910716166.

Ferrante, L., Duczmal, L., Steinmetz, W. A., Almeida, A. C. L., Leão, J., Vassão, R. C., ... \& Fearnside, P. M. (2021). How Brazil's President turned the country into a global epicenter of COVID-19. Journal of Public Health Policy, 42, 439-451.https://doi.org/10.1057/s41271-021-00302-0

Fonseca, E. M. D., Nattrass, N., Lazaro, L. L. B., \& Bastos, F. I. (2021). Political discourse, denialism and leadership failure in Brazil's response to COVID-19. Global Public Health, 16(8-9), 12511266. https://doi.org/10.1080/17441692.2021.1945123

Freeman, D., Waite, F., Rosebrock, L., Petit, A., Causier, C., East, A., ... \& Lambe, S. (2020). Coronavirus conspiracy beliefs, mistrust, and compliance with government guidelines in England. Psychological medicine, 1-13. https://doi.org/10.1017/S0033291720001890

G1, O Globo, Extra, Estadão, Folha, \& UOL. (2020, June 9). Veículos de comunicação formam parceria para dar transparência a dados de Covid-19. G1. Retrieved September 23, 2021, from https://g1. globo.com/politica/noticia/2020/06/08/veiculos-de-comunicacao-formam-parceria-para-dar-trans parencia-a-dados-de-covid-19.ghtml

Gadarian, S. K., Goodman, S. W., \& Pepinsky, T. B. (2021). Partisanship, health behavior, and policy attitudes in the early stages of the COVID-19 pandemic. PLOS ONE, 16(4), e0249596. https://doi. org/10.1371/journal.pone.0249596

Galhardi, C. P., Freire, N. P., Minayo, M. C. D. S., \& Fagundes, M. C. M. (2020). Fato ou Fake? Uma análise da desinformação frente à pandemia da Covid-19 no Brasil. Ciência \& Saúde Coletiva, 25, 4201-4210. https://doi.org/10.1590/1413-812320202510.2.28922020

Galli, L. M., \& Modesto, J. G. (2021). A Influência das Crenças Conspiratórias e Orientação Política na Vacinação. Revista de Psicologia da IMED, 13(1), 179-193. https://doi.org/10.18256/2175-5027. 2021.v13i1.4491 
Gramacho, W. G., \& Turgeon, M. (2021). When politics collides with public health: COVID-19 vaccine country of origin and vaccination acceptance in Brazil. Vaccine, 39(19), 2608-2612. https://doi.org/ 10.1016/j.vaccine.2021.03.080

Guerin, O. (2021, July 9). Covid-19 pandemic: “Everything you should not do, Brazil has done.” BBC News. Retrieved September 23, 2021, from https://www.bbc.com/news/world-latin-america-57733 540

Guess, A. M., Lerner, M., Lyons, B., Montgomery, J. M., Nyhan, B., Reifler, J., \& Sircar, N. (2020). A digital media literacy intervention increases discernment between mainstream and false news in the United States and India. Proceedings of the National Academy of Sciences, 117(27), 15536-15545. https://doi.org/10.1073/pnas.1920498117

Hallwass, L. C. L., \& Bredow, V. H. (2021). WhatsApp como ambiente de interação social e aprendizagens durante o ensino remoto emergencial. Revista Educação e Emancipação 14(2) 62-83. https:// doi.org/10.18764/2358-4319.v14n2p62-83

Jost, J. T., Glaser, J., Kruglanski, A. W., \& Sulloway, F. J. (2003). Political conservatism as motivated social cognition. Psychological Bulletin, 129(3), 339-375. https://doi.org/10.1037/0033-2909.129.3. 339

Kahan, D. M. (2012). Ideology, motivated reasoning, and cognitive reflection: An experimental study. Judgment and Decision Making, 8, 407-424. https://doi.org/10.2139/ssrn.2182588

Kahan, D. M. (2017). Misconceptions, misinformation, and the logic of identity-protective cognition. Yale Law \& Economics Research Paper, (587). https://doi.org/10.2139/ssrn.2973067

Keersmaecker, J., \& Roets, A. (2017). 'Fake news': Incorrect, but hard to correct. The role of cognitive ability on the impact of false information on social impressions. Intelligence, 65, 107-110. https:// doi.org/10.1016/j.intell.2017.10.005

Lewandowsky, S., \& Van Der Linden, S. (2021). Countering misinformation and fake news through inoculation and prebunking. European Review of Social Psychology, 22, 1-38. https://doi.org/10. 1080/10463283.2021.1876983

Lima, I. C. V. D., Galvão, M. T. G., Pedrosa, S. C., Cunha, G. H. D., \& Costa, A. K. B. (2018). Uso do aplicativo Whatsapp no acompanhamento em saúde de pessoas com HIV: Uma análise temática. Escola Anna Nery, 22(3), e20170429. https://doi.org/10.1590/2177-9465-EAN-2017-0429

Lupion, B. (2021, June 19). Quantas mortes poderiam ter sido evitadas no Brasil? DW. Retrieved November 17, 2021, from https://www.dw.com/pt-br/quantas-mortes-poderiam-ter-sido-evita das-no-brasil/a-57950639

Médicos pela Vida. (2021, February 16). Médicos pela Vida - Covid19 - Manisfesto. Médicos Pela Vida - Covid19. Retrieved September 23, 2021, from https://www.medicospelavidacovid19.com. $\mathrm{br} / \mathrm{manifesto} /$ ?_ga=2.71591763.1508062765.1631144684-1246101990.1631144684

Militão, E. (2021, March 3). Imprensa criou pânico sobre covid, diz Bolsonaro enquanto mortes sobem 11\%. UOL Notícias. Retrieved September 23, 2021, from https://noticias.uol.com.br/polit ica/ultimas-noticias/2021/03/03/bolsonaro-volta-a-criticar-imprensa-e-preve-pronunciamentosobre-pandemia.htm

Modesto, J. G., Zacarias, D. O., Galli, L. M., \& Neiva, B. D. A. (2020). COVID-19 and attitudes toward social isolation: The role of political orientation, morality, and fake news. Estudos de Psicologia (Natal), 25(2), 124-132. https://doi.org/10.22491/1678-4669.20200013

Monari, A. C. P., de Araújo, K. M., de Souza, M. R., \& Sacramento, I. (2021). Legitimando um populismo anticiência: análise dos argumentos de Bolsonaro sobre vacinação contra Covid-19 no Twitter. Liinc em Revista, 17(1), e5707. https://doi.org/10.18617/liinc.v17i1.5707

Ognyanova, K., Lazer, D., Robertson, R. E., \& Wilson, C. (2020). Misinformation in action: Fake news exposure is linked to lower trust in media, higher trust in government when your side is in power. Harvard Kennedy School (HKS) Misinformation Review,1(4). https://doi.org/10.37016/ mr-2020-024

Jovem Pan. (2018, February 5). "Até agora o primo pobre está com chance”, diz Bolsonaro sobre eleição. Retrieved September 23, 2021, from https://jovempan.com.br/programas/panico/ateagora-o-primo-pobre-esta-com-chance-diz-bolsonaro-sobre-eleicao-2.html

Pazhoohi, F., \& Kingstone, A. (2021). Associations of political orientation, xenophobia, right-wing authoritarianism, and concern of COVID-19: Cognitive responses to an actual pathogen threat. Personality and Individual Differences, 182, 111081. https://doi.org/10.1016/j.paid.2021.111081

Pennycook, G., \& Rand, D. G. (2019). Lazy, not biased: Susceptibility to partisan fake news is better explained by lack of reasoning than by motivated reasoning. Cognition, 188, 39-50. https://doi. org/10.1016/j.cognition.2018.06.011 
Pennycook, G., \& Rand, D. G. (2021). The psychology of fake news. Trends in Cognitive Sciences, 25(5), 388-402. https://doi.org/10.1016/j.tics.2021.02.007

Pinto, L. B., Silva, J. P. X., de Oliveira, V. R., Ferreira, M. L. S., de Freitas, K. M., \& Vieira, R. P. (2021). Implicações das fake news nas práticas de vacinação: relatos produzidos pela equipe de enfermagem. Research Society and Development, 10(10), e575101018997. https://doi.org/10. 33448/rsd-v10i10.18997

Poder360. (2021, June 18). Médicos também defenderam a vacina e criticaram a prescrição de remédios por não-médicos e kit covid. Poder360. Retrieved September 23, 2021, from https://www. poder360.com.br/congresso/especialistas-defendem-uso-de-remedios-como-cloroquina-e-iverm ectina-a-cpi/

Prichard, E. C., \& Christman, S. D. (2020). Authoritarianism, conspiracy beliefs, gender and COVID19: Links between individual differences and concern about COVID-19, mask wearing behaviors, and the tendency to blame China for the virus. Frontiers in Psychology, 11, 3130. https:// doi.org/10.3389/fpsyg.2020.597671

Ramos, G., Vieites, Y., Jacob, J., \& Andrade, E. B. (2020). Orientação política e apoio ao isolamento social durante a pandemia da COVID-19: Evidências do Brasil. Revista De Administração Pública, 54, 697-713. https://doi.org/10.1590/0034-761220200162

Ricard, J., \& Medeiros, J. (2020). Using misinformation as a political weapon: COVID-19 and Bolsonaro in Brazil. Harvard Kennedy School (HKS) Misinformation Review, 1(3). https://doi.org/ 10.37016/mr-2020-013

Rodrigues, P. F., Ribeiro, M. M., Camargo, C., \& Massad, E. (2021). COVID-19 epidemics in Brazil: Political influences on its incidence and the economic impacts of its mortality. SSRN Electronic Journal. Preprint. (June 15, 2021). Retrieved September 23, 2021. Available at SSRN: https:// ssrn.com/abstract $=3867770$ or https://doi.org/10.2139/ssrn.3867770

Roozenbeek, J., van der Linden, S., \& Nygren, T. (2020). Prebunking interventions based on the psychological theory of "inoculation" can reduce susceptibility to misinformation across cultures. Harv Kennedy Sch Misinformation Rev, 1(2), 1-23. https://doi.org/10.37016/mr-2020-008

Roozenbeek, J., Schneider, C. R., Dryhurst, S., Kerr, J., Freeman, A. L., Recchia, G., ... \& Van Der Linden, S. (2020). Susceptibility to misinformation about COVID-19 around the world. Royal Society open science, 7(10), 201199.https://doi.org/10.1098/rsos.201199

Rothgerber, H., Wilson, T., Whaley, D., Rosenfeld, D. L., Humphrey, M., Moore, A., \& Bihl, A. (2020). Politicizing the covid-19 pandemic: Ideological differences in adherence to social distancing. PsyArXiv. https://doi.org/10.31234/osf.io/k23cv

Secom TCU. (2021, August 4). Aplicativo TrateCov recomendava tratamento precoce da Covid-19. TCU. Retrieved September 23, 2021, from https://portal.tcu.gov.br/imprensa/noticias/aplicativo-tratecovrecomendava-tratamento-precoce-da-covid-19.htm

Silva, R. M. (2021). COVID-19 in Brazil: The catastrophic results of an inappropriate and unequal health policy. Ethics, Medicine, and Public Health, 18, 100673. https://doi.org/10.1016/j.jemep.2021. 100673

Soares, I., \& Fernandes, A. (2021, April 5). Robôs entram em ação para ajudar Bolsonaro diante da crise sanitária brasileira. Correio Brasiliense. Retrieved September 23, 2021, from https://www. correiobraziliense.com.br/politica/2021/04/4916144-robos-entram-em-acao-para-ajudar-bolsonarodiante-da-crise-sanitaria-brasileira.html

Soares, F. B., Recuero, R., Volcan, T., Fagundes, G., \& Sodré, G. (2021). Research note: Bolsonaro's firehose: How Covid-19 disinformation on WhatsApp was used to fight a government political crisis in Brazil. Harvard Kennedy School (HKS) Misinformation Review, 2(1). https://doi.org/10.37016/ mr-2020-54

Soares, I. (2021, September 14). Bolsonaro defende MP das redes sociais: "Fake news faz parte da nossa vida." Correio Braziliense. Retrieved September 23, 2021, from https://www.correiobraziliense. com.br/politica/2021/09/4949494-bolsonaro-defende-mp-das-redes-sociais-fake-news-faz-parte-danossa-vida.html

Stanley, M. L., Barr, N., Peters, K., \& Seli, P. (2021). Analytic-thinking predicts hoax beliefs and helping behaviors in response to the COVID-19 pandemic. Thinking \& Reasoning, 27(3), 464-477. https:// doi.org/10.1080/13546783.2020.1813806

Van Bavel, J. J., \& Pereira, A. (2018). The partisan brain: An identity-based model of political belief. Trends in Cognitive Sciences, 22(3), 213-224. https://doi.org/10.1016/j.tics.2018.01.004 
Van Hiel, A., \& De Clercq, B. (2009). Authoritarianism is good for you: Right-wing authoritarianism as a buffering factor for mental distress. European Journal of Personality, 23(1), 33-50. https://doi.org/ 10.1002/per.702

Van Der Linden, S., Roozenbeek, J., \& Compton, J. (2020). Inoculating against fake news about COVID19. Frontiers in Psychology, 11, 2928. https://doi.org/10.3389/fpsyg. 2020.566790

Vilanova, F., Sousa, D. A. D., Koller, S. H., \& Costa, A. B. (2018). Adaptação transcultural e estrutura fatorial da versão brasileira da escala Right-Wing Authoritarianism. Trends in Psychology, 26, 1299-1316. https://doi.org/10.9788/TP2018.3-07Pt

Werneck, G. L., Bahia, L., Moreira, J. P. L., \& Scheffer, M. (2021, June). Mortes Evitáveis por Covid19 no Brasil. alerta.org.br. Retrieved September 23, 2021, from http://idec.org.br/sites/default/files/ mortes_evitaveis_por_covid-19_no_brasil_para_internet_1.pdf

Zhu, D., Mishra, S. R., Han, X., \& Santo, K. (2020). Social distancing in Latin America during the COVID-19 pandemic: An analysis using the Stringency Index and Google Community Mobility Reports. Journal of travel medicine, 27(8), taaa12. https://doi.org/10.1093/jtm/taaa125 